\title{
JOB QUALITY IN SCOTLAND
}

\author{
John Sutherland
}

\begin{abstract}
This article examines job quality and job satisfaction for individuals who are employed at workplaces located in Scotland. Using a series of indices constructed from responses in the survey of employees associated with the 2011 Workplace and Employment Relations Study, it investigates how job quality and job satisfaction differ across individuals. It also examines whether job quality and job satisfaction for individuals employed in Scotland are different from individuals employed elsewhere in Britain. Individuals employed at workplaces in Scotland are seen to have positive perspectives about the quality of their jobs. Although most maintain that they work very hard, nonetheless they are seen to have considerable control over most aspects of their jobs; are confident about their job security; and view their workplace managers as being supportive. In terms of differences across individuals, who have higher (lower) levels of job quality depends upon the index of job quality used. With the exception of their pay, individuals are seen to be satisfied with all aspects of their jobs, although the level of satisfaction does vary across individuals. There is little difference between employees located in Scotland and employees located elsewhere in Britain with respect to either job quality or job satisfaction.
\end{abstract}

Keywords: Job quality: Job satisfaction: Workplace and Employment Relations Study, 2011 (WERS, 2011): Survey of Employees

\section{Context and Motivation}

Although there are no universally accepted defining characteristics of what constitutes 'job quality', nevertheless there is a degree of unanimity that its potential impact is both extensive and profound at the level of the individual, the employing organisation and society at large. For example, and to illustrate, for the individual 'good' jobs are associated with psychological well-being, skills use and skills development and good pay with job satisfaction, whereas 'bad' jobs are associated with physical and psychological illnesses, stress and job strain, low pay and in work poverty. For the employing

John Sutherland is an Honorary Research Fellow at the Scottish Centre for Employment Research (SCER) in the Department of Human Resource Management at the University of Strathclyde, 
Glasgow: email: john.sutherland@strath.ac.uk. He acknowledges the constructive comments made on an earlier draft of this article. 
organisation at the level of its workplace, 'good' jobs are associated with a well-paid, committed and engaged workforce who enhance productivity, competitiveness and profitability, whereas 'bad' jobs are associated with high levels of sickness and absenteeism, poor levels of health and safety, and hence high levels of work related injury, and high levels of labour turnover. At the level of society as a whole, whereas a dominating prevalence of 'good' jobs promotes good health and positive wellbeing on the part of most if not necessarily all of the population, the costs of 'bad' jobs are externalised to the tax and benefits systems, and are reflected in reduced tax revenues and high levels of health and welfare spending.

That said job quality is a contextual concept. The meaning of what constitutes job quality is not self- evident. Workers' assessments of what are good/bad jobs vary; and what is deemed to be a 'bad' job by one may be deemed to be a 'good' job by another (Sutherland, 2012).

There is a well-established history of policy relevant academic research which relates to job quality. However, job quality has entered the policy debate only within the last two decades principally as a consequence of influential publications from supranational organisations, notably the EU and the ILO. And, now, job quality has formally entered policy debate in Scotland.

In June, 2015, the Economy, Energy and Tourism committee of the Scottish Parliament announced an inquiry into work, wages and wellbeing in the Scottish labour market that will explore how employment and job quality has changed since the recession. Its terms of reference include examining the characteristics and contrasting qualities of different jobs; the health, social and economic impacts of low pay and low quality work; and the extent to which Scottish Government policies can improve the quality of work and the wellbeing of workers in Scotland (Scottish Parliament, 2015).

The numbers in employment in Scotland rose from 2.440 million in the first quarter of 2010 to 2.622 million in the first quarter of 2015 , an increase of 182,000 (or 7.5 per cent). Such an increase is typical rather than atypical of post-recession periods because the demand for labour increases as the economy re-expands to reach its pre-recessionary levels. Nevertheless, there has been considerable disquiet voiced about the quality of some of the jobs created during this particular period (e.g. Boyd, 2014: Darby et al, 2014: Fraser, 2015). For example the number of jobs created in low productivity-low paid sectors of the economy; the number of jobs created which are part time; the number of part time jobs held, often involuntarily, by individuals on zero-hours contracts; and the number of individuals described as self-employed.

The nature of the employment contract and its conditions of employment, reflected in wage rates, hours of work available and earnings levels, for example, are important extrinsic features of job quality. The intrinsic features of work, however, such as the intensity with which individuals are 
required to work and the extent of the discretion they have over their jobs are also important. There is much less statistical information available about these features of work, particularly in Scotland. Furthermore, job quality, however measured, influences job satisfaction, a constituent part of worker well-being which has also been an important addition to the policy agenda across Europe during this century (European Commission, 2001). Again, there is little statistical information about this for Scotland.

There are many indices of job quality and job satisfaction (Green, 2006). This article makes use of several sets of indices of both which have their origin in responses to the survey of employees, a component of the Workplace and Employment Relations Study to address the following questions as they pertain to individuals employed at workplaces located in Scotland:

- How do individuals rate their jobs, for example in terms of how hard they must work and the extent of their task discretion? Do these ratings differ according to the job aspect in question? Do they differ across individuals?;

- How satisfied are individuals with their jobs? Does satisfaction differ according to the job aspect in question? Does it differ across individuals?; and

- With reference to both job quality and job satisfaction, in what way are the perspectives of individuals employed at workplaces which are located in Scotland different from the perspectives of others employed at workplaces located elsewhere in Britain?

The aims of the article are deliberately descriptive. Its novelty arises from its originality in presenting some quantitative answers to the questions posed.

\section{The Workplace and Employment Relations Study Data Set [1]}

The data set analysed in this article is a sub population of the matched merger of two data sets associated with the 2011 Workplace Employment Relations Study (hereafter WERS 2011) viz. responses to the management questionnaire (which includes the establishment's employee profile); and responses to the survey of employees.

WERS 2011 is the sixth in a series of workplace surveys which map the changing contours of employment relations in Britain (Brown et al, 2009). The population sampled is all workplaces in Britain which have five or more employees operating in Sections C-S of the 2007 Standard Industrial Classification (i.e. Agriculture and Mining are excluded), where a workplace is defined as comprising the activities of a single employer at a single set of premises. The population sampled accounts for 35 per cent of all workplaces and 90 per cent of all employees (van Wanrooy et al, 2013). 
At each participating workplace, the most senior manager responsible for employment relations/human resources/personnel was interviewed. This is referred to as 'the management questionnaire'. Prior to this interview, this manager was asked to provide a demographic profile of the workplace. This is referred to as the 'employee profile'. Further, permission was sought to distribute a self-completion questionnaire to employees at the workplace. Where the manager agreed, 25 employees were selected at random from a list of employees and invited to complete the questionnaire. At workplaces with fewer than 25 employees, each employee was invited to participate. This is referred to as the 'survey of employees'.

2,680 workplaces participated in the survey, of which 276 (10.3 per cent) were located in Scotland. 2,170 (in Scotland, 235) managers agreed to have the survey of employees conducted at their workplaces. 21,981 of the survey forms were returned, with 2,481 (10.9 per cent) of those returned coming from individuals at workplaces located in Scotland. The 2,481 employees constitute the (weighted) sub population which is analysed below. [2]

\section{Job Quality}

The foci for most examinations of job quality are the principal features of an individual's job and the nature of his/her working environment (Brown et al, 2007: Karasek, 1979: Green, 2011: Green and Whitfield, 2009). There are four components to this which ultimately constitute indices of job quality viz. 'job demands'; 'job control'; 'job security'; and 'job supports'.

'Job demands' - often referred to as 'work intensity' (Green, 2006) - is examined in the survey of employees by means of analysing responses to two statements: 'my job requires that I work very hard'; and 'I never seem to have enough time to get my work done'. The percentage distribution of responses to these two statements is presented in Table 1. Although (approximately) four in five workers either 'strongly agree' or 'agree' that their jobs require them to work very hard, nonetheless only (approximately) two in five either 'strongly agree' or 'agree' that they are given inadequate time to do this.

\section{Insert Table 1 near here}

'Job control' - often referred to as 'job autonomy' or 'task discretion' (Karasek, 1979) - is examined in the survey by asking employees about the extent of their influence over five features of their jobs viz. the tasks done; the pace of work; how the work is done; the order in which tasks are carried out; and the time work is started and finished. The percentage distribution of responses to these questions is presented in Table 2. This table indicates that at least (approximately) 40 per cent of employees have 'a lot' of control over four of the five work features specified. The exception is the time their work starts and finishes, over which 30 per cent (approximately) have no control 
whatsoever. Again with the exception of the time work starts and finishes, only small minorities of employees have no control over the specified features of their work.

Insert Table 2 near here

'Job security' is investigated by examining responses to the statement that 'I feel my job is secure in this workplace'. The percentage distribution of responses is reported in Table 3.

Confidence in their job security is relatively high, with approximately three in five workers either agreeing or strongly agreeing with the statement put, perhaps a surprisingly high percentage given the economic environment prevailing at the time of the survey (McManus and Perry, 2012).

Insert Table 3 near here

'Job supports' - indicative of a supportive management which is assumed to help counter some of the effects of job demands (Wood, 2008) - is examined in the survey by asking employees about their perceptions of management at the workplace with regard to the six issues identified in column 1 of Table 4. Generally, employees view their workplace management to be supportive. With one exception, more than 50 per cent either 'agree' or 'strongly agree' with the statements put. The exception relates to 'promises', where less than 50 per cent of the respondents report that managers can be relied upon to keep their promises.

\section{Insert Table 4 near here}

To investigate the manner in which these four components of job quality, both separately and in total, vary by factors such as an individual's personal characteristics and the characteristics of the workplace at which he/she is employed, five indices of job quality are generated. First, the responses to each question/statement identified above for each of the four components of job quality are treated as scalar variables (where the highest (lowest) number is accorded to the highest (lowest) level of job quality), re-coding the original responses where necessary. Then these scalar variables are aggregated, where appropriate, to produce four separate indices of job quality. Finally, the four separate indices of 'job demands', 'job control', 'job security' and 'job supports' thus generated are aggregated to produce an index of 'total job quality'. Each index is then then analysed as a dependent variable in a series of ordinary least squares (OLS) regressions.

The OLS model used to estimate the co-variates of these five indices of job quality conforms to convention viz.:

$$
y_{i}=\alpha+X_{i} \beta+\varepsilon
$$

where ' $y$ ' is the dependent variable; $\alpha$ a constant; $X$ a vector of independent variables (which denote the personal characteristics of the individual and the characteristics of the workplace at which he/she is employed); $\beta$ a set of coefficients to be estimated and $\varepsilon$ a random error term (Wooldridge, 
2009). Full details about the independent variables included in the model estimated may be seen from column 1 in Table A2 in the Statistical Appendix. [3]

The detailed results of these estimations of the five indices of job quality are reported in Tables A2 through to A6 in the Statistical Appendix. Given the origin and the manner in which the indices were constructed, it is perhaps preferable to focus more upon the signs of the coefficients of the independent variables (and their levels of statistical significance) rather than their numerical values. In this respect, a coefficient which is positively (negatively) signed is interpreted as being positively (negatively) correlated with the appropriate dependent variable and, therefore, associated with higher (lower) levels of job quality, as measured by the index in question.

From the perspective of the individual worker, jobs are indivisible, containing, to different degrees, attributes associated with what have been identified as 'job demands'; 'job controls'; 'job security'; and 'job supports'. Consequently, it is practical to begin the discussion of these results with Table A2, which reports the results as they apply to 'total job quality'. There are three points of note in this table. First, total job quality is higher for individuals working in smaller workplaces (relative to the reference size category of 100 -199 employees). Secondly, in contrast, total job quality is lower for individuals who have a health problem; who are union members; and who work in the public sector. Thirdly, variables such as gender, age, graduate status, contract type and tenure are of no consequence.

As it is constructed, however, the 'total job quality' index is the aggregate of its four constituent parts and it is important to note how some of the outcomes change when a disaggregated analysis is made of each of the four separate indices of job quality (cf. Tables A3 -A6 in the Statistical Appendix).

The relatively small workplace size variables are of consequence only in the context of 'job controls' and 'job supports'. Individuals working in relatively small workplaces may have higher job quality in terms of their task discretion and managerial support, but not necessarily in terms of either work intensification or job security. In the disaggregated analysis, the health variable is statistically significant only in the context of the regression of 'job demands'. Individuals who have a health problem have lower job quality in terms of work intensification, but not in the context of the three other constituent components of total job quality. Individuals who are union members have lower job quality in terms of 'job demands', 'job controls' and 'job supports'. In contrast, in the regression of 'job security', this variable is positively signed, but not statistically significant. Perhaps not surprisingly given the environment prevailing at the time of the survey, individuals who work in the public sector have lower levels of job quality across all four disaggregated indices, although only the result for 'job security' is statistically significant. 
Further, some of the variables which were of no consequence in the context of the regression of 'total job quality' prove to be of some consequence in some parts of the disaggregated analysis. Indeed, the variable female is statistically significant in all four estimations. Females, relative to males, have higher levels of job quality for 'job controls'; 'job security'; and 'job supports'; but lower levels of job quality for 'job demands'. The set of variables denoting the age categories is of occasional consequence. (Where all age categories are relative to the reference category of an individual aged $30-39$ ) job quality in terms of job demands is higher for those in the under 21; 22 29; and 60 or over age categories. However, if not necessarily unexpectedly, job quality is lower in terms of job controls for those in the under 21 age category; and lower in terms of job security for those in the $40-49$ and $50-59$ age categories. The variable denoting graduate status is statistically significant in one estimation. Individuals who are graduates, relative to those who are not, have higher levels of job quality in the context of job supports. The variable denoting the nature of the contract of employment held by individuals is of consequence in two estimations. Relative to individuals who have permanent contracts of employment, the reference category, individuals who do not hold permanent contracts of employment have higher levels of job quality in the context of job supports; but, not unexpectedly, lower levels of job quality in the context of job security. Finally, the set of variables denoting workplace tenure appear to be of little consequence. Only one variable is statistically significant - that denoting that an individual has been employed at the workplace for less than one year - and this is statistically significant in two estimations. Relative to those employed at the workplace for between two and five years, the reference category, individuals who have been employed at the workplace for less than one year have higher levels of job quality in terms of both job demands and job supports.

Who have higher or lower levels of job quality, therefore, depends very much upon the index used to measure job quality.

\section{Job Satisfaction}

Job satisfaction is an affective (or emotive) response towards various aspects of an individual's job, although implicitly there is some element of comparison involved, for example with some alternative position such as another job previously held or a job held by another. Whereas mainstream economics presents work as a source of disutility, other perspectives suggest that some individuals in some circumstances may derive degrees of satisfaction from it (Spencer, 2009). There is a degree of consensus in the empirical literature about the principal determinants of job satisfaction. Ceteris paribus, males, individuals in their 30s, individuals with higher levels of education and individuals working in larger establishments tend to have lower levels of job satisfaction (e.g. Clark,1996: Gazioglu and Tansel, 2006). 
In the survey of employees, job satisfaction is investigated by asking 'how satisfied' individuals were with eight aspects of their jobs. These aspects are identified in column 1 of Table 5, which also reports the percentage distribution of responses across the five response options. In general, the picture presented is one of a satisfied workforce. Nonetheless, 18 per cent reported being either dissatisfied or very dissatisfied with the training received; 19 per cent reported being either dissatisfied or very dissatisfied with the opportunity to develop skills on the job; and (as much as) 33 per cent reported being either dissatisfied or very dissatisfied with the pay received.

Insert Table 5 near here

To investigate the manner in which job satisfaction in total varies by factors such as an individual's personal characteristics and the characteristics of the workplace at which he/she is employed, the responses to each of the eight aspects are treated as scalar variables (where the highest (lowest) number is accorded to the highest (lowest) level of satisfaction); these numbers are then aggregated across the eight aspects of job satisfaction. Finally, the aggregate number is analysed as a dependent variable in an OLS regression model which contains the same set of independent variables used in the earlier regressions of job quality.

The results are reported in Table A7 in the Statistical Appendix and these are not too dissimilar from those obtained in previous studies of job satisfaction.

Women, relative to men, report higher levels of job satisfaction. Job satisfaction is also higher for those aged 60 and over (relative to the reference age category of $30-39$ ); those with workplace tenure of less than one year (relative to the reference category of being employed at the workplace for two to less than five years); and those employed at workplaces with less than 100 employees (relative to those employed at workplaces employing $100-199$, the reference category). However, the level of job satisfaction is lower for those aged $40-49$ (again relative to the appropriate reference category); those with a health problem; and those who work in the public sector (relative to those employed in the private sector, the reference category).

\section{Job Satisfaction and Job Quality}

Job satisfaction is one dimension of employee well-being, an increasingly important feature in the recent policy agenda (Layard, 2011). Further, psychological theories emphasise the salience of job quality as an influence upon employee well-being (Karasek, 1979). Consequently, an additional avenue for investigation is the nature of the co-relation which exists between the index of job satisfaction and the several indexes of job quality.

This co-relation is examined in two ways, both applying the model outlined previously used to estimate job satisfaction. First, the index of total job quality is added as an independent variable to the set of variables in the original model. The results of this exercise are reported in Table A8 in 
the Statistical Appendix. Secondly, the four separate indices of the constituent components of 'total' job quality are added as independent variables to the set of variables in the original model. The results of this exercise are reported in Table A9 in the Statistical Appendix. To economise on space, only the results for the additional variables are reported in each instance.

In their different ways, the results of both regressions demonstrate the high positive corelation between job satisfaction and job quality. Further, the values of the respective coefficients in the second exercise illustrate the relative importance of the four discrete components of total job quality, with that for job security being much the largest. Inevitably, in both estimations, the inclusion of the additional variables makes marginal modifications to the values of the coefficients of the other variables relative to their values in the first estimation of job satisfaction. However, what is most apparent from the latter estimations is the manner in which the inclusion of the additional job quality related variables increases the value of the R-squared i.e. the fraction of the variance of the dependent variable job satisfaction which is explained is increased considerably.

\section{Is Scotland 'Different'?}

Thus far, what have been examined have been the determinants of job quality and job satisfaction for the sub population of individuals working at establishments which are located in Scotland in the WERS 2011 survey of employees. This prompts the question: "to what extent - if at all - does job quality and job satisfaction for individuals employed at workplaces located in Scotland differ from the job quality and job satisfaction of individuals working at establishments which are located elsewhere in Britain?" The workplaces about which individuals report their perspectives of job quality, variously measured, and express their levels of satisfaction with diverse aspects of their jobs do not exist in a geographical vacuum. The economic process often assigns particular functions or roles to particular places. As a consequence, the economic landscape is spatially differentiated and management's recruitment and labour control strategies are often adjusted accordingly. And the spatial division of labour of labour which results, once manifest nationally is now apparent internationally, following globalisation (Dicken, 2014).

This research question is addressed by repeating the five original estimations of job quality and the one estimation of job satisfaction for the whole population sampled in the survey of employees, and adding to the set of independent variables included in the original model a set of independent variables which denote the standard statistical regions (SSRs) of Britain.

The results for these six re-estimations are reported in Tables A10 through to A15 in the Statistical Appendix. Again to economise on space, only the results for the independent variables denoting the SSRs are presented. In these estimations 'Scotland' was identified as the 'reference 
category'. Consequently, positively (negatively) signed coefficients indicate standard statistical regions which have higher (lower) levels of job quality, as indexed, and job satisfaction. [4]

There are two outcomes worthy of note in the context of job quality. First, across the five estimations which relate to job quality, the principal feature is one of negatively signed coefficients for the nine SSRs. Indeed, relative to Scotland, job quality across all five indices is lower in five SSRs viz. Yorkshire and Humberside, East Midlands, the South East, the South West and the West Midlands. Partly by way of contrast, job quality is higher in Wales across four of the five indices, the exception being the estimation of job demands. Secondly, very few of these results are statistically significant. The results in the estimation of job demands index are an exception. Here, of the coefficients associated with the nine SSRs, five are statistically significant (and all are negatively signed).

In the context of the estimation of job satisfaction, the pattern of positively/negatively signed coefficients of the SSRs is very different. Five are negatively signed and four are positively signed. However, only one is statistically significant.

In general, therefore, there would appear to be little statistically significant difference in either job quality or job satisfaction between employees in workplaces located in Scotland and employees in workplaces located elsewhere in Britain. If there is a qualification it relates to the job demands index of job quality.

\section{Conclusions}

There are three statistical conclusions of consequence. First, individuals employed at workplaces in Scotland have generally positive perspectives about the quality of their jobs. Although most maintain that they must work very hard, nonetheless they have considerable control over most aspects of their jobs; they are confident about their job security; and they view their workplace managers as being supportive. In terms of differences across individuals, however, who have higher (lower) levels of job quality depends upon the index of job quality used. Secondly, with the exception of their pay, individuals are satisfied with all aspects of their jobs. Again the level of satisfaction (dissatisfaction) varies across individuals. Finally, there would appear to be little difference between employees in workplaces located in Scotland and employees in workplaces located elsewhere in Britain with respect to either job quality or job satisfaction

The results reported in this article, however, are descriptive snapshots from the year 2011, obtained from a particular workplace survey which is GB based. What is required is a more sophisticated analysis of job quality and job satisfaction of employees in Scotland. In this analysis, if questionnaire responses are to be treated as scalar dependent variables in any estimation models, the complementary use of standardised coefficients is required. Certainly, there is a need to add a 
quantitative element to the discussions about the correlations reported. Finally, there is a need for a process of hypotheses setting and hypotheses testing to examine why observed differences are as they are. To do so, however, requires a data set appropriate for this purpose.

Hopefully, one conclusion which will emanate from the Economy, Energy and Tourism committee's inquiry will be the need to devise and administer a survey which will produce a data set which will facilitate this type of analysis. Ultimately, however, both job quality and job satisfaction depend upon developments in the wider economy, notably the impacts of globalisation and technical change, and the practices of employers, for example about how they choose to make use of these technical changes in the way they organise work and how they choose to manage their human resources. Over time, therefore, as the impacts of these developments and practices change, so, too, job quality and job satisfaction change. For example, some good jobs can become bad jobs and some bad jobs can become even worse. Ideally one would also like to track and examine these changes. Any proposed survey, therefore, must be undertaken at regular intervals in the future. Only in this way will the necessary information be gathered to ensure that policies designed to improve the quality of work and the wellbeing of workers in Scotland will be evidence-based.

\section{Endnotes}

[1] The Workplace Employment Relations Study, 2011 was sponsored by: the Department for Business, Innovation and Skills (BIS), the Economic and Social Research Council (ESRC), the UK Commission for Employment and Skills (UKCES), the Advisory, Conciliation and Arbitration Service (ACAS) and the National Institute of Economic and Social Research (NIESR). The principal investigators were: BIS, ACAS, and NIESR. The data were collected by NatCen Social Research. The data were deposited at the UK Data Archive (UKDA) by BIS. The data were accessed via UKDA. Crown copyright is held jointly with ESRC, UKCES, ACAS and NIESR. Crown copyright material is reproduced with the permission of the Controller of HMSO and the Queen's Printer for Scotland. None of the above parties bears any responsibility for the analysis of the data set undertaken or any interpretation made from this analysis. The bibliographic citation for this data collection is: Department for Business, Innovation and Skills, Advisory, Conciliation and Arbitration Service and National Institute of Economic and Social Research, Workplace Employee Relations Survey, 2011 [computer file]. Colchester, Essex: UK Data Archive [distributor], February, 2013. SN: 7226, http://dx.doi.org/10.5255/UKDA-SN-7226-1.

[2] For further information about the study design, the sampling process, sampling errors, weighting etc. refer to the Technical Appendix in van Wanrooy et al (2013). 
[3] Given the nature of the independent variables in the model estimated, there is an inevitable degree of multicollinearity between some. The extent of this, however, is not deemed to be detrimental to the model specified and applied.

[4] When observations have incomplete information across all the variables in the model, they are automatically dropped from the estimation in question. This explains why the number of observations reported differs across the estimations (and from the number of observations reported in Table A1). There is nothing that indicates that this process of elimination is anything other than random.

[5] In the estimations which make use of the original full data set the differences between the values of the coefficients and the levels of the statistical significance of the other variables and the same for the Scotland sub population are negligible.

\section{References}

Boyd, S. (2014) Labour market changes and implications for policy and labour market information (LMI) in Scotland. Fraser of Allender Economic Commentary, vol. 38, no. 2, 63 -80.

Brown, A., Charlewood, A., Forde, C. and Spencer, D. (2007) Job quality and the economics of new Labour: a critical appraisal using subjective survey data. Cambridge Journal of Economics, vol. 31, $941-971$.

Brown, W., Bryson, A., Forth, J. and Whitfield, K. (2009) The Evolution of the Modern Workplace. Cambridge: Cambridge University Press.

Clark, A.E. (1996) Job satisfaction in Britain. British Journal of Industrial Relations, vol. 34, no. 2, 189 217.

Darby, J. and McIntyre, S.G. (2014) The Post crisis labour market and the challenge to policy makers. Fraser of Allender Economic Commentary, vol. 38, no. 2, 51 -62.

Dicken, P. (2014) Global Shift: Mapping the Changing Contours of the World Economy. London: Sage Publications, seventh edition.

European Commission (2001) Employment and Social Policies: A Framework for Investing in Quality. Communication from the Commission to the Council, the European Parliament, the Economic and Social Committee and the Committee of the Regions. Brussels: European Commission.

Fraser, D. (2015) Is your job a flexible friend or foe? http://www.BBC/Scotland, $18^{\text {th }}$ April, 2015 [Accessed 11 May 2015].

Gazioglu, S. and Tansel, A. (2006) Job satisfaction in Britain: individual and job related factors. Applied Economics, vol. 38, no. 10, 1163 -1171.

Green, F. (2006) Demanding Work: The Paradox of Job Quality in the Affluent Economy. Princeton, New Jersey, USA: Princeton University Press. 
Green, F. (2011) Job quality in Britain under the Labour government. In P. Gregg and J. Wadsworth (eds.), The Labour Market in Winter: The State of Working Britain, 111 -127. Oxford: Oxford University Press.

Green, F. and Whitfield, K. (2009) Employees' experience of work. In W. Brown, A. Bryson, J. Forth and K. Whitfield (eds.), The Evolution of the Modern Workplace, 201 -229. Cambridge: Cambridge University Press.

Karasek, R.A. (1979) Job demands, job decision latitude and mental strain: implications for job redesign. Administrative Science Quarterly, vol. 24, no. 2, 285 -308.

Layard, R. (2011) Happiness: Lessons from a New Science. London and New York, USA: Penguin Books.

McManus, S. and Perry, J. (2012) Hard work? Employment, life-work balance and well-being in the changing economy. In A. Park, E. Clery, J. Curtice, M. Phillips and D. Uttings (eds.) British Social Attitudes: The $29^{\text {th }}$ Report, 99 -115. London: NatCen.

Scottish Parliament (2015) Work, wages and wellbeing in the Scottish labour market. http://www.scottishparliament.uk/parliamentarybusiness/currentcommittees/90669.aspx (accessed 28.10.2015).

Spencer, D. (2009) The Political Economy of Work. London: Routledge.

Sutherland, J. (2012) Job attribute preferences: who prefers what? Employee Relations, Vol. 34, No. 2, pp $193-221$.

van Wanrooy, B., Bewley, H., Bryson, A., Forth, J., Freeth, S., Stokes, L. and Wood, S. (2013) Employment Relations in the Shadow of Recession. Basingstoke: Palgrave Macmillan.

Wood, S. (2008) Job characteristics, employee voice and well-being in Britain. Industrial Relations Journal, vol. 39, no. 2, $153-168$.

Wooldridge, J.M. (2009) Introductory Econometrics: A Modern Approach. South-Western, USA: Centage Learning, fifth edition. 
Table 1

'Job Demands': Percentage Distribution of Responses to the Statements Identified

\begin{tabular}{|l|r|r|r|r|r|r|}
\hline & $\begin{array}{l}\text { Strongly } \\
\text { Agree }\end{array}$ & Agree & $\begin{array}{l}\text { Neither } \\
\text { Agree } \\
\text { nor } \\
\text { Disagree }\end{array}$ & Disagree & $\begin{array}{l}\text { Strongly } \\
\text { Disagree }\end{array}$ & $\begin{array}{l}\text { Number } \\
\text { of } \\
\text { Observations }\end{array}$ \\
\hline $\begin{array}{l}\text { My job requires that I work } \\
\text { very hard }\end{array}$ & 34.7 & 47.4 & 14.2 & 3.0 & 0.4 & 2376 \\
\hline $\begin{array}{l}\text { I never seem to have } \\
\text { enough time to get my work } \\
\text { done }\end{array}$ & 15.4 & 25.7 & 29.4 & 25.4 & 3.9 & 2358 \\
\hline
\end{tabular}

Footnote to Tables $1-5$ :

All percentages are rounded, hence the totals may not equal ' 100 '.

Table 2

'Job Controls': Percentage Distribution of Responses to the Features Identified (all of which begin with the preamble "In general, how much influence do you have over ...."

\begin{tabular}{|l|r|r|r|r|r|}
\hline & None & A Little & Some & A Lot & $\begin{array}{l}\text { Number of } \\
\text { Observations }\end{array}$ \\
\hline The tasks you do? & 9.0 & 10.9 & 37.3 & 42.6 & 2386 \\
\hline The pace at which you work? & 7.9 & 11.8 & 38.4 & 41.6 & 2379 \\
\hline How you do your work? & 3.0 & 8.6 & 32.7 & 55.5 & 2381 \\
\hline The order in which tasks are carried out? & 4.5 & 8.9 & 32.8 & 53.6 & 2380 \\
\hline The time at which work is started and finished? & 31.3 & 13.4 & 23.9 & 31.2 & 2373 \\
\hline
\end{tabular}

Table 3

'Job Security': Percentage Distribution of Responses to the Statement: "I feel my job is secure at this workplace"

\begin{tabular}{|r|r|l|r|r|r|}
\hline Strongly Disagree & Disagree & $\begin{array}{l}\text { Neither Disagree nor } \\
\text { Agree }\end{array}$ & Agree & Strongly Agree & $\begin{array}{l}\text { Number of } \\
\text { Observations }\end{array}$ \\
\hline 4.2 & 12.7 & 20.9 & 45.2 & 16.8 & 2291 \\
\hline
\end{tabular}

Table 4

'Job Supports': Percentage Distribution of Responses to the Statements Identified (where each statement is prefaced with the phrase 'Management here...'

\begin{tabular}{|l|r|r|r|r|r|r|}
\hline & $\begin{array}{l}\text { Strongly } \\
\text { Disagree }\end{array}$ & Disagree & $\begin{array}{l}\text { Neither } \\
\text { Disagree } \\
\text { Nor Agree }\end{array}$ & Agree & $\begin{array}{l}\text { Strongly } \\
\text { Agree }\end{array}$ & $\begin{array}{l}\text { Number of } \\
\text { Observations }\end{array}$ \\
\hline $\begin{array}{l}\text { Can be relied upon to keep } \\
\text { their promises }\end{array}$ & 5.5 & 16.3 & 29.7 & 37.8 & 10.5 & 2366 \\
\hline $\begin{array}{l}\text { Are sincere in attempting to } \\
\text { understand employees' } \\
\text { views }\end{array}$ & 4.9 & 15.8 & 23.2 & 43.7 & 12.1 & 2372 \\
\hline $\begin{array}{l}\text { Deal with employees } \\
\text { honestly }\end{array}$ & 4.6 & 13.3 & 25.4 & 43.9 & 12.6 & 2357 \\
\hline $\begin{array}{l}\text { Understand about } \\
\text { employees' responsibilities } \\
\text { outside work }\end{array}$ & 3.8 & 11.1 & 23.3 & 47.4 & 14.2 & 2353 \\
\hline $\begin{array}{l}\text { Encourage people to } \\
\text { develop their skills }\end{array}$ & 3.6 & 11.7 & 25.6 & 44.8 & 14.0 & 2371 \\
\hline
\end{tabular}




\begin{tabular}{|l|r|r|r|r|r|r|}
\hline Treat employees fairly & 5.2 & 13.6 & 24.6 & 41.7 & 14.6 & 2371 \\
\hline
\end{tabular}

Table 5

'Job Satisfaction': Percentage Distribution of Responses by Job Aspect (Where the opening clause to each is: "How satisfied are you with.....)

\begin{tabular}{|l|r|r|r|r|r|r|}
\hline Aspect & $\begin{array}{l}\text { Very } \\
\text { Dissatisfied }\end{array}$ & Dissatisfied & $\begin{array}{l}\text { Neither } \\
\text { Dissatisfied } \\
\text { Nor } \\
\text { Satisfied }\end{array}$ & Satisfied & $\begin{array}{l}\text { Very } \\
\text { Satisfied }\end{array}$ & $\begin{array}{r}\text { Number of } \\
\text { Observations }\end{array}$ \\
\hline $\begin{array}{l}\text { The sense of } \\
\text { achievement from } \\
\text { the work? }\end{array}$ & 2.2 & 5.6 & 18.9 & 51.2 & 21.9 & 2392 \\
\hline $\begin{array}{l}\text { The scope for } \\
\text { using your own } \\
\text { initiative? }\end{array}$ & 1.6 & 6.1 & 17.6 & 50.6 & 24.0 & 2393 \\
\hline $\begin{array}{l}\text { The amount of } \\
\text { influence you } \\
\text { have over your } \\
\text { job? }\end{array}$ & 2.1 & 10.6 & 27.4 & 44.2 & 15.5 & 2374 \\
\hline $\begin{array}{l}\text { The training you } \\
\text { receive? }\end{array}$ & 4.7 & 14.5 & 25.8 & 42.9 & 11.8 & 2378 \\
\hline $\begin{array}{l}\text { The opportunity } \\
\text { to develop your } \\
\text { skills in your job? }\end{array}$ & 5.0 & 14.9 & 27.4 & 39.7 & 12.7 & 2382 \\
\hline $\begin{array}{l}\text { The amount of } \\
\text { pay you receive? }\end{array}$ & 10.2 & 23.3 & 22.7 & 36.3 & 7.3 & 2394 \\
\hline $\begin{array}{l}\text { Your job security } \\
\text { The work itself? }\end{array}$ & 4.7 & 11.2 & 22.9 & 47.3 & 13.6 & 2331 \\
\hline
\end{tabular}




\section{Statistical Appendix}

Table A1 presents descriptive statistics for the dependent variables used in the estimations reported.

Tables A2 - A5 report the OLS regression results for the five estimations associated with 'job quality'.

Table A7 reports the OLS regression results for the estimation of the dependent variable 'total job satisfaction'.

Tables A8 and A9 report the OLS regression results for job satisfaction when variables associated with job quality are included as independent variables in the model.

Tables A10 - A15 report the regression results for the five estimations associated with job quality and the one estimation of job satisfaction when the full data set is used and when variables associated with the Standard Statistical Regions are included as independent variables. 
Table A1

Descriptive Statistics for the Dependent Variables in the OLS Regressions Associated with 'Job Quality' and 'Job Satisfaction' for the 'Scotland' Sub Population

\begin{tabular}{|l|r|r|r|r|r|}
\hline Variable Name & Minimum & Maximum & Mean & $\begin{array}{l}\text { Standard } \\
\text { Deviation }\end{array}$ & $\begin{array}{l}\text { Number of } \\
\text { Observations }\end{array}$ \\
\hline Total Job Quality & 10 & 58 & 39.09 & 7.95 & 2121 \\
\hline Job Demands & 2 & 10 & 4.61 & 1.62 & 2347 \\
\hline Job Controls & 0 & 15 & 10.45 & 3.57 & 2335 \\
\hline Job Security & 1 & 5 & 3.47 & 1.09 & 2291 \\
\hline Job Supports & 6 & 30 & 20.52 & 5.37 & 2288 \\
\hline Total Job Satisfaction & 8 & 40 & 20.52 & 5.37 & 2271 \\
\hline
\end{tabular}


Table A2

OLS Results: Dependent Variable 'Total Job Quality'

\begin{tabular}{|c|c|c|c|}
\hline Variable & Coefficient & $\begin{array}{l}\text { Linearized } \\
\text { Std. Err. }\end{array}$ & $P>|t|$ \\
\hline Female & .7429 & .4640 & 0.109 \\
\hline $\begin{array}{l}\text { Age categories } \\
\text { Aged } 21 \text { or under }\end{array}$ & -.2076 & .9450 & 0.826 \\
\hline Aged $22-29$ & .8679 & .7956 & 0.281 \\
\hline Aged 30 -39 (reference category) & & & \\
\hline Aged $40-49$ & -.6900 & .5638 & 0.221 \\
\hline Aged $50-59$ & .5028 & .4756 & 0.291 \\
\hline Aged 60 or over & 1.6681 & .8063 & 0.039 \\
\hline Graduate & .6128 & .4031 & 0.129 \\
\hline Health problem & -1.4880 & .7599 & 0.050 \\
\hline Union member & -1.1400 & .5386 & 0.034 \\
\hline $\begin{array}{l}\text { Not on a permanent contract of } \\
\text { Employment }\end{array}$ & 1.2504 & .8001 & 0.118 \\
\hline $\begin{array}{l}\text { Tenure categories } \\
\text { Less than } 1 \text { year }\end{array}$ & 1.3059 & .7237 & 0.071 \\
\hline 1 to less than 2 years & .2362 & .8394 & 0.778 \\
\hline $\begin{array}{l}2 \text { to less than } 5 \text { years (reference } \\
\text { category) }\end{array}$ & & & \\
\hline 5 to less than 10 years & -.4337 & .6026 & 0.472 \\
\hline 10 years or more & -.0983 & .6001 & 0.870 \\
\hline $\begin{array}{l}\text { Workplace size categories } \\
\text { Less than } 25 \text { employees }\end{array}$ & 3.3678 & .8554 & 0.000 \\
\hline 25 - 49 employees & 2.0249 & .9984 & 0.043 \\
\hline $50-99$ employees & 1.2072 & .8738 & 0.167 \\
\hline $\begin{array}{l}100 \text {-199 employees (reference } \\
\text { category) }\end{array}$ & & & \\
\hline $200-499$ employees & 1.7642 & 1.0202 & 0.084 \\
\hline 500 or more employees & .8654 & .7138 & 0.225 \\
\hline Working in the public sector & -1.0909 & .6148 & 0.076 \\
\hline Constant & & & \\
\hline Number of observations & & & 1917 \\
\hline$F(36,2574)=$ & & & 8.19 \\
\hline Prob $>F=$ & & & 0.0000 \\
\hline R-squared & & & 0.1213 \\
\hline
\end{tabular}

Footnote to Tables A2 -A6:

Additionally, the regression included the following independent variables: whether unions were present at the workplace; the individual's pay categories; the log of the number of hours the individual normally worked; and whether the individual worked at an establishment management declared had been affected by the recession. Details of these results are not reported because these variables were seen primarily as 'control' rather than potential 'explanatory' variables. 
Table A3

OLS Results: Dependent Variable 'Job Demands'

\begin{tabular}{|c|c|c|c|}
\hline Variable & Coefficient & $\begin{array}{l}\text { Linearized } \\
\text { Std. Err. }\end{array}$ & $P>|t|$ \\
\hline Female & -.5793 & .0893 & 0.000 \\
\hline $\begin{array}{l}\text { Age categories } \\
\text { Aged } 21 \text { or under }\end{array}$ & 1.0651 & 1626 & 0.000 \\
\hline Aged $22-29$ & .0602 & .1264 & 0.040 \\
\hline \multicolumn{4}{|l|}{ Aged 30 -39 (reference category) } \\
\hline Aged $40-49$ & .1907 & .1250 & 0.127 \\
\hline Aged $50-59$ & .1043 & .1203 & 0.386 \\
\hline Aged 60 or over & .4246 & .1540 & 0.006 \\
\hline Graduate & -.1245 & .0869 & 0.152 \\
\hline Health problem & -.3112 & .1503 & 0.039 \\
\hline Union member & -.2500 & .0990 & 0.012 \\
\hline $\begin{array}{l}\text { Not on a permanent contract of } \\
\text { Employment }\end{array}$ & -.1711 & .2094 & 0.414 \\
\hline $\begin{array}{l}\text { Tenure categories } \\
\text { Less than } 1 \text { year }\end{array}$ & .2767 & .1274 & 0.030 \\
\hline 1 to less than 2 years & .0428 & .1627 & 0.793 \\
\hline \multicolumn{4}{|l|}{$\begin{array}{l}2 \text { to less than } 5 \text { years (reference } \\
\text { category) }\end{array}$} \\
\hline 5 to less than 10 years & .1652 & .1158 & 0.154 \\
\hline 10 years or more & .0226 & .1143 & 0.843 \\
\hline $\begin{array}{l}\text { Workplace size categories } \\
\text { Less than } 25 \text { employees }\end{array}$ & .1396 & .2081 & 0.502 \\
\hline $25-49$ employees & -.0880 & .2182 & 0.687 \\
\hline $50-99$ employees & -.2173 & .1815 & 0.231 \\
\hline \multicolumn{4}{|l|}{$\begin{array}{l}100 \text {-199 employees (reference } \\
\text { category) }\end{array}$} \\
\hline $200-499$ employees & .1009 & .2032 & 0.619 \\
\hline 500 or more employees & .0952 & .1642 & 0.562 \\
\hline Working in the public sector & -.1615 & .1291 & 0.211 \\
\hline \multicolumn{4}{|l|}{ Constant } \\
\hline Number of observations & & & 2107 \\
\hline$F(36,2574)=$ & & & 15.46 \\
\hline Prob $>F=$ & & & 0.0000 \\
\hline R-squared & & & 0.1755 \\
\hline
\end{tabular}


Table A4

OLS Results: Dependent Variable 'Job Controls'

\begin{tabular}{|c|c|c|c|}
\hline Variable & Coefficient & $\begin{array}{l}\text { Linearized } \\
\text { Std. Err. }\end{array}$ & $P>|t|$ \\
\hline Female & .4007 & .1930 & 0.038 \\
\hline $\begin{array}{l}\text { Age categories } \\
\text { Aged } 21 \text { or under }\end{array}$ & -.1 .0379 & .4558 & 0.023 \\
\hline Aged $22-29$ & .2531 & .3450 & 0.463 \\
\hline \multicolumn{4}{|l|}{ Aged 30 -39 (reference category) } \\
\hline Aged $40-49$ & -.0469 & .2561 & 0.855 \\
\hline Aged $50-59$ & .1278 & .2422 & 0.598 \\
\hline Aged 60 or over & .6754 & .4225 & 0.110 \\
\hline Graduate & .2103 & .1677 & 0.210 \\
\hline Health problem & -.4932 & .3006 & 0.101 \\
\hline Union member & -.4907 & .2305 & 0.033 \\
\hline $\begin{array}{l}\text { Not on a permanent contract of } \\
\text { Employment }\end{array}$ & .5860 & .3863 & 0.129 \\
\hline $\begin{array}{l}\text { Tenure categories } \\
\text { Less than } 1 \text { year }\end{array}$ & -.2657 & .3452 & 0.441 \\
\hline 1 to less than 2 years & -.0011 & .3415 & 0.997 \\
\hline \multicolumn{4}{|l|}{$\begin{array}{l}2 \text { to less than } 5 \text { years (reference } \\
\text { category) }\end{array}$} \\
\hline 5 to less than 10 years & .0708 & .2464 & 0.774 \\
\hline 10 years or more & .3799 & .2725 & 0.163 \\
\hline $\begin{array}{l}\text { Workplace size categories } \\
\text { Less than } 25 \text { employees }\end{array}$ & 1.2515 & .3656 & 0.001 \\
\hline 25 - 49 employees & .4768 & .4023 & 0.236 \\
\hline $50-99$ employees & .7570 & .3669 & 0.039 \\
\hline \multicolumn{4}{|l|}{$\begin{array}{l}100 \text {-199 employees (reference } \\
\text { category) }\end{array}$} \\
\hline $200-499$ employees & .2362 & .4947 & 0.633 \\
\hline 500 or more employees & .5641 & .3327 & 0.090 \\
\hline Working in the public sector & -.1737 & .2734 & 0.525 \\
\hline \multicolumn{4}{|l|}{ Constant } \\
\hline Number of observations & & & 2096 \\
\hline$F(36,2575)=$ & & & 12.82 \\
\hline Prob $>F=$ & & & 0.0000 \\
\hline R-squared & & & 0.1233 \\
\hline
\end{tabular}


Table A5

OLS Results: Dependent Variable 'Job Security'

\begin{tabular}{|c|c|c|c|}
\hline Variable & Coefficient & $\begin{array}{l}\text { Linearized } \\
\text { Std. Err. }\end{array}$ & $P>|t|$ \\
\hline Female & .1759 & .0548 & 0.001 \\
\hline $\begin{array}{l}\text { Age categories } \\
\text { Aged } 21 \text { or under }\end{array}$ & .1056 & 1370 & 0.441 \\
\hline Aged $22-29$ & .0748 & .0823 & 0.363 \\
\hline \multicolumn{4}{|l|}{ Aged 30 -39 (reference category) } \\
\hline Aged $40-49$ & -.2678 & .0724 & 0.000 \\
\hline Aged $50-59$ & -.1673 & .0740 & 0.024 \\
\hline Aged 60 or over & .0532 & .1206 & 0.659 \\
\hline Graduate & -.1048 & .0676 & 0.122 \\
\hline Health problem & .0137 & .1028 & 0.893 \\
\hline Union member & .0393 & .0580 & 0.498 \\
\hline $\begin{array}{l}\text { Not on a permanent contract of } \\
\text { Employment }\end{array}$ & -.5785 & .1309 & 0.000 \\
\hline $\begin{array}{l}\text { Tenure categories } \\
\text { Less than } 1 \text { year }\end{array}$ & .0987 & .0864 & 0.254 \\
\hline 1 to less than 2 years & -.0157 & .1172 & 0.893 \\
\hline \multicolumn{4}{|l|}{$\begin{array}{l}2 \text { to less than } 5 \text { years (reference } \\
\text { category) }\end{array}$} \\
\hline 5 to less than 10 years & -.0225 & .0821 & 0.783 \\
\hline 10 years or more & .0215 & .0878 & 0.806 \\
\hline $\begin{array}{l}\text { Workplace size categories } \\
\text { Less than } 25 \text { employees }\end{array}$ & .0335 & .1193 & 0.776 \\
\hline 25 - 49 employees & -.0562 & .1084 & 0.604 \\
\hline $50-99$ employees & .0985 & .1117 & 0.378 \\
\hline \multicolumn{4}{|l|}{$\begin{array}{l}100 \text {-199 employees (reference } \\
\text { category) }\end{array}$} \\
\hline $200-499$ employees & .0054 & .1508 & 0.971 \\
\hline 500 or more employees & .0172 & .0952 & 0.856 \\
\hline Working in the public sector & -.2702 & .0796 & 0.001 \\
\hline \multicolumn{4}{|l|}{ Constant } \\
\hline Number of observations & & & 2056 \\
\hline$F(36,2574)=$ & & & 4.17 \\
\hline Prob $>F=$ & & & 0.0000 \\
\hline R-squared & & & 0.0725 \\
\hline
\end{tabular}


Table A6

OLS Results: Dependent Variable 'Job Supports'

\begin{tabular}{|c|c|c|c|}
\hline Variable & Coefficient & $\begin{array}{l}\text { Linearized } \\
\text { Std. Err. }\end{array}$ & $P>|t|$ \\
\hline Female & .6791 & .2955 & 0.022 \\
\hline $\begin{array}{l}\text { Age categories } \\
\text { Aged } 21 \text { or under }\end{array}$ & -.8081 & .5952 & 0.175 \\
\hline Aged $22-29$ & .1664 & .4853 & 0.732 \\
\hline \multicolumn{4}{|l|}{ Aged $30-39$ (reference category) } \\
\hline Aged $40-49$ & -.5857 & .3611 & 0.105 \\
\hline Aged $50-59$ & .2847 & .3363 & 0.397 \\
\hline Aged 60 or over & .0743 & .5501 & 0.893 \\
\hline Graduate & .7125 & .3270 & 0.030 \\
\hline Health problem & -.7481 & .5359 & 0.163 \\
\hline Union member & -.5898 & .3223 & 0.067 \\
\hline $\begin{array}{l}\text { Not on a permanent contract of } \\
\text { Employment }\end{array}$ & 1.2084 & .4702 & 0.010 \\
\hline $\begin{array}{l}\text { Tenure categories } \\
\text { Less than } 1 \text { year }\end{array}$ & 1.3974 & .4742 & 0.003 \\
\hline 1 to less than 2 years & .1533 & .5476 & 0.780 \\
\hline \multicolumn{4}{|l|}{$\begin{array}{l}2 \text { to less than } 5 \text { years (reference } \\
\text { category) }\end{array}$} \\
\hline 5 to less than 10 years & -.9766 & .3892 & 0.012 \\
\hline 10 years or more & -.6656 & .3759 & 0.077 \\
\hline $\begin{array}{l}\text { Workplace size categories } \\
\text { Less than } 25 \text { employees }\end{array}$ & 2.1069 & .5860 & 0.000 \\
\hline 25 - 49 employees & 1.6128 & .7157 & 0.024 \\
\hline $50-99$ employees & .4776 & .6417 & 0.457 \\
\hline \multicolumn{4}{|l|}{$\begin{array}{l}100 \text {-199 employees (reference } \\
\text { category) }\end{array}$} \\
\hline $200-499$ employees & 1.5033 & .6677 & 0.024 \\
\hline 500 or more employees & .4302 & .5156 & 0.404 \\
\hline Working in the public sector & -.5234 & .4241 & 0.217 \\
\hline \multicolumn{4}{|l|}{ Constant } \\
\hline Number of observations & & & 2047 \\
\hline$F(36,2575)=$ & & & 6.61 \\
\hline Prob $>F=$ & & & 0.0000 \\
\hline R-squared & & & 0.1225 \\
\hline
\end{tabular}


Table A7

OLS Results: Dependent Variable 'Total Job Satisfaction'

\begin{tabular}{|c|c|c|c|}
\hline Variable & Coefficient & $\begin{array}{l}\text { Linearized } \\
\text { Std. Err. }\end{array}$ & $P>|t|$ \\
\hline Female & 1.2254 & .3178 & 0.000 \\
\hline $\begin{array}{l}\text { Age categories } \\
\text { Aged } 21 \text { or under }\end{array}$ & -4607 & .7382 & 0533 \\
\hline Aged $22-29$ & .1877 & .5436 & 0.730 \\
\hline Aged 30 -39 (reference category) & & & \\
\hline Aged $40-49$ & -.8738 & .3665 & 0.017 \\
\hline Aged $50-59$ & -1569 & .4249 & 0.712 \\
\hline Aged 60 or over & 1.3570 & .6724 & 0.044 \\
\hline Graduate & -.3522 & .3072 & 0.252 \\
\hline Health problem & -1.3435 & .5110 & 0.009 \\
\hline Union member & -.1896 & .3268 & 0.562 \\
\hline $\begin{array}{l}\text { Not on a permanent contract of } \\
\text { Employment }\end{array}$ & .6337 & .5649 & 0.262 \\
\hline Tenure categories & & & \\
\hline Less than 1 year & 1.9782 & .5803 & 0.001 \\
\hline 1 to less than 2 years & .0413 & .5787 & 0.943 \\
\hline $\begin{array}{l}2 \text { to less than } 5 \text { years (reference } \\
\text { category) }\end{array}$ & & & \\
\hline 5 to less than 10 years & -.1013 & .4164 & 0.808 \\
\hline 10 years or more & .3935 & .4835 & 0.416 \\
\hline $\begin{array}{l}\text { Workplace size categories } \\
\text { Less than } 25 \text { employees }\end{array}$ & 1.2352 & .5736 & 0.031 \\
\hline 25 - 49 employees & 1.1561 & .5321 & 0.030 \\
\hline $50-99$ employees & 9922 & .5330 & 0.063 \\
\hline $\begin{array}{l}100 \text {-199 employees (reference } \\
\text { category) }\end{array}$ & & & \\
\hline 200 -499 employees & 2750 & .5663 & 0.627 \\
\hline 500 or more employees & 5779 & 4619 & 0.211 \\
\hline Working in the public sector & -1.2701 & .3710 & 0.001 \\
\hline Constant & & & \\
\hline Number of observations & & & 2042 \\
\hline$F(36,2574)=$ & & & 11.37 \\
\hline Prob $>F=$ & & & 0.0000 \\
\hline R-squared & & & 0.1333 \\
\hline
\end{tabular}

Footnote to Table A7:

Refer to the footnote of Table A2. 
Table A8

OLS Regression Results: Dependent Variable 'Total Job Satisfaction'

\begin{tabular}{|l|c|c|r|}
\hline Variable & Coefficient & $\begin{array}{l}\text { Linearized } \\
\text { Std. Err. }\end{array}$ & $\mathrm{P}>|\mathrm{t}|$ \\
\hline 'Total' Job Quality & .5004 & .0171 & 0.0000 \\
\hline & & & \\
\hline Number of Observations & & & 1867 \\
\hline $\mathrm{F}(37,2572)=$ & & & 49.06 \\
\hline Prob $>\mathrm{F}=$ & & & 0.0000 \\
\hline R-squared & & & 0.5488 \\
\hline
\end{tabular}

Footnote to Tables A8 and A9:

Additionally, the model estimated contained all the variables included in the previously reported regressions.

Table A9

OLS Regression Results: Dependent Variable 'Total Job Satisfaction'

\begin{tabular}{|l|r|r|r|}
\hline Variable & Coefficient & $\begin{array}{l}\text { Linearized } \\
\text { Std. Err. }\end{array}$ & $\mathrm{P}>|\mathrm{t}|$ \\
\hline 'Job Demands' & .1997 & .0689 & 0.004 \\
\hline 'Job Control' & .3892 & .0362 & 0.000 \\
\hline 'Job Security' & 1.4675 & .1066 & 0.000 \\
\hline 'Job Supports' & .4779 & .0217 & 0.000 \\
\hline & & & \\
\hline Number of Observations & & & 1867 \\
\hline F(40, 2569) & & & 54.04 \\
\hline Prob > F & & & 0.0000 \\
\hline R-squared & & & 0.5852 \\
\hline
\end{tabular}


Table A10

Regression Results: Dependent Variable 'Job Demands'

\begin{tabular}{|l|r|r|r|}
\hline Variable & Coefficient & $\begin{array}{l}\text { Linearized } \\
\text { Std. Err. }\end{array}$ & $\mathrm{P}>|\mathrm{t}|$ \\
\hline North & -.2019 & .0822 & 0.014 \\
\hline Yorkshire and Humberside & -.0565 & .1061 & 0.594 \\
\hline East Midlands & -.1933 & .0852 & 0.023 \\
\hline East Anglia & -.1170 & .0861 & 0.175 \\
\hline South East & -.0398 & .0627 & 0.525 \\
\hline South West & -.0695 & .0911 & 0.445 \\
\hline West Midlands & -.3075 & .0696 & 0.000 \\
\hline North West & -.2859 & .0933 & 0.002 \\
\hline Wales & -.2446 & .0943 & 0.010 \\
\hline Scotland (reference category) & & & \\
\hline & & & \\
\hline Number of Observations & & & 19301 \\
\hline F(45, 1860) & & & 27.96 \\
\hline Prob > F & & & 0.0000 \\
\hline R-squared & & & 0.1067 \\
\hline
\end{tabular}

Footnote to Tables A10 - A15

For information on the additional independent variables included in the estimations, refer to the previous tables providing OLS results, together with the footnotes to these tables

Table A11

Regression Results: Dependent Variable 'Job Control'

\begin{tabular}{|l|r|r|r|}
\hline Variable & Coefficient & $\begin{array}{l}\text { Linearized } \\
\text { Std. Err. }\end{array}$ & $\mathrm{P}>|\mathrm{t}|$ \\
\hline North & -.2363 & .2575 & 0.359 \\
\hline Yorkshire and Humberside & -.2306 & .1755 & 0.189 \\
\hline East Midlands & -.1571 & .1967 & 0.425 \\
\hline East Anglia & -.4339 & .2474 & 0.080 \\
\hline South East & -.3547 & .1385 & 0.011 \\
\hline South West & -.2787 & .1927 & 0.148 \\
\hline West Midlands & -.0840 & .1745 & 0.630 \\
\hline North West & .0681 & .1989 & 0.732 \\
\hline Wales & .0365 & .2263 & 0.872 \\
\hline Scotland (reference category) & & & \\
\hline & & & \\
\hline Number of Observations & & & 19238 \\
\hline F(45, 1862) & & & 22.77 \\
\hline Prob > F & & & 0.0000 \\
\hline R-squared & & & 0.1051 \\
\hline
\end{tabular}


Table A12

Regression Results: Dependent Variable 'Job Security'

\begin{tabular}{|l|r|r|r|}
\hline Variable & Coefficient & $\begin{array}{l}\text { Linearized } \\
\text { Std. Err. }\end{array}$ & $\mathrm{P}>|\mathrm{t}|$ \\
\hline North & .0070 & .0734 & 0.924 \\
\hline Yorkshire and Humberside & -.1310 & .0919 & 0.154 \\
\hline East Midlands & -.0182 & .0603 & 0.762 \\
\hline East Anglia & .0078 & .0727 & 0.914 \\
\hline South East & -.0837 & .0460 & 0.069 \\
\hline South West & -.1061 & .0759 & 0.163 \\
\hline West Midlands & -.0525 & .0644 & 0.415 \\
\hline North West & -.1135 & .0559 & 0.043 \\
\hline Wales & .0069 & .0776 & 0.929 \\
\hline Scotland (reference category) & & & \\
\hline & & & \\
\hline Number of Observations & & & 18948 \\
\hline F(45, 1860) & & & 15.84 \\
\hline Prob > F & & & 0.0000 \\
\hline R-squared & & & 0.0876 \\
\hline
\end{tabular}

Table A13

Regression Results: Dependent Variable 'Job Support'

\begin{tabular}{|l|r|r|r|}
\hline Variable & Coefficient & $\begin{array}{l}\text { Linearized } \\
\text { Std. Err. }\end{array}$ & $P>|\mathrm{t}|$ \\
\hline North & .2338 & .3068 & 0.446 \\
\hline Yorkshire and Humberside & -.2100 & .3215 & 0.514 \\
\hline East Midlands & -.1288 & .3044 & 0.672 \\
\hline East Anglia & -.6238 & .3660 & 0.088 \\
\hline South East & -.1700 & .2278 & 0.456 \\
\hline South West & -.0190 & .2710 & 0.944 \\
\hline West Midlands & -.2367 & .3179 & 0.457 \\
\hline North West & -.0935 & .3042 & 0.758 \\
\hline Wales & .7904 & .4495 & 0.079 \\
\hline Scotland (reference category) & & & \\
\hline & & & \\
\hline Number of Observations & & & 18676 \\
\hline F(45, 1859) & & & 18.43 \\
\hline Prob > F & & & 0.0000 \\
\hline R-squared & & & 0.0921 \\
\hline
\end{tabular}


Table A14

Regression Results: Dependent Variable 'Total Job Quality'

\begin{tabular}{|l|r|r|r|}
\hline Variable & Coefficient & $\begin{array}{l}\text { Linearized } \\
\text { Std. Err. }\end{array}$ & $\mathrm{P}>|\mathrm{t}|$ \\
\hline North & .0181 & .5068 & 0.971 \\
\hline Yorkshire and Humberside & -.5773 & .4478 & 0.198 \\
\hline East Midlands & -.3764 & .4673 & 0.421 \\
\hline East Anglia & -1.1639 & .5729 & 0.042 \\
\hline South East & -.6404 & .3290 & 0.052 \\
\hline South West & -.4391 & .4136 & 0.289 \\
\hline West Midlands & -.6767 & .4652 & 0.146 \\
\hline North West & -.4218 & .4778 & 0.377 \\
\hline Wales & .6028 & .5874 & 0.305 \\
\hline Scotland (reference category) & & & \\
\hline & & & \\
\hline Number of Observations & & & 17582 \\
\hline F(45, 1855) & & & 19.30 \\
\hline Prob > F & & & 0.0000 \\
\hline R-squared & & & 0.1042 \\
\hline
\end{tabular}

Table A15

Regression Results: Dependent Variable 'Job Satisfaction'

\begin{tabular}{|l|r|r|r|}
\hline Variable & Coefficient & $\begin{array}{l}\text { Linearized } \\
\text { Std. Err. }\end{array}$ & $P>|\mathrm{t}|$ \\
\hline North & .2737 & .3395 & 0.420 \\
\hline Yorkshire and Humberside & -.3329 & .3465 & 0.337 \\
\hline East Midlands & .2905 & .3243 & 0.370 \\
\hline East Anglia & .3167 & .3392 & 0.352 \\
\hline South East & -.5595 & .2387 & 0.019 \\
\hline South West & -.1802 & .3067 & 0.557 \\
\hline West Midlands & -.0228 & .3532 & 0.956 \\
\hline North West & -.1220 & .3256 & 0.708 \\
\hline Wales & .2859 & .4238 & 0.500 \\
\hline Scotland (reference category) & & & \\
\hline & & & \\
\hline Number of Observations & & & 18708 \\
\hline F(45, 1858) & & & 15.76 \\
\hline Prob > F & & & 0.0000 \\
\hline R-squared & & & 0.0770 \\
\hline
\end{tabular}

